\title{
New challenge to nuclear test facility
}

[WASHINGTON] Environmental groups are expected to mount a last-ditch court action this week to block construction of the National Ignition Facility (NIF), which is due to start at Lawrence Livermore National Laboratory in California.

A total of 50 groups, led by the Natural Resources Defense Council (NRDC), will ask the Federal District Court in Washington for a preliminary injunction to block construction work. They will argue that the Department of Energy (DoE) failed properly to consider alternatives to its Science-based Stockpile Stewardship Program, of which the NIF is a central component, for maintaining the US nuclear weapons stockpile.

The environmentalists will charge that an extensive Programmatic Environmental Impact Statement, completed by DoE last November, failed to assess broad alternatives such as the remanufacture of weapons to existing designs.

The NIF will attempt to ignite tiny pellets of deuterium-tritium fuel by firing 192 extremely powerful laser beams at it. Ignition occurs if fusion in the fuel releases enough energy to sustain itself. A study by the National Academy of Sciences, released last month, concluded that current scientific understanding gives "a reasonable expectation that ignition will be achieved".

But both opponents and proponents of the NIF argue that DoE is keen to build it whether it achieves ignition or not because of the weapons-physics experiments it will do and because of its role in retaining top-rate physicists at weapons laboratories.

The academy report lists a number of targets set in 1990 for Nova, the existing inertial confinement fusion machine at Livermore, which have not been met. These include maximum temperature at the target and the "convergence ratio", a measure of how tightly pellets are compressed.

But the report still concludes that the NIF will make "important contributions" to stockpile stewardship, and should proceed as planned. Although court action by the NRDC blocked the DoE from using the academy report, the department decided to proceed with the project in any case (see Nature 386, 209; 1997).

Steve Koonin of the California Institute of Technology, who chaired the academy panel, is confident that the problems can be overcome. But he said it was impossible to put a number on the "reasonable" probability that the machine would achieve ignition: "Reasonable means to me that a prudent physicist would go ahead and do it."

Koonin said that he was proud to have participated in the academy process, and criticized Tom Cochran, the senior arms control analyst at the NRDC. "I only wish that Tom Cochran was subject to the same kind of peer review that the committee was subject to." He said that "there wasn't much technical expertise" in the NRDC's submissions to the panel.

Cochran was unavailable for comment but Christopher Paine, another NRDC analyst, accused the academy committee of bias towards NIF. "We don't say these people are dishonorable - just that the committee was unbalanced", he said. Paine pointed out that the committee estimated that NIF would now cost $\$ 1.6$ billion, including Livermore's own costs, against the widely assumed figure of $\$ 1.1$ billion.

"The days of building \$1-billion machines that were fantastic flops are gone," he said. "The reason NIF has got so far is that it is riding on the back of stockpile stewardship. The preponderance of evidence is that it isn't ready - the academy concedes as much when it says it has a 'reasonable' chance of working."

Colln Macllwain

\section{White House science office 'needs more focus', says panel}

[WASHINGTON] The Office of Science and Technology Policy (OSTP) in the US White House should have a more tightly defined role in the process of setting the president's annual budget and should employ a chief of staff, according to a memorandum released by the Carnegie Commission.

The commission, an independent panel set up in 1988 with backing from the Carnegie Corporation, also says that the National Science and Technology Council (NSTC), the cabinet-level body responsible for coordinating science and technology across the administration, should concentrate on a smaller number of policy issues of importance to the president.

Since the start of the first Clinton administration in 1993, OSTP has been led by Jack Gibbons, previously director of the Office of Technology Assessment. OSTP is supposed to help Gibbons to advise the president on science and technology issues. Through the NSTC, it is also intended to coordinate science and technology policy across the federal government.

But the office has recently been criticized as lacking influence in the White House. Last month, Congressman George Brown (California, Democrat) told Science and Government Report, a Washington newsletter: "I don't think he [Gibbons] is winning the bat-

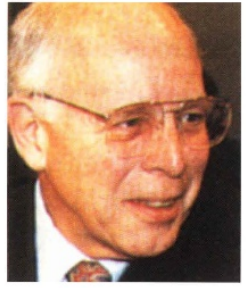

Gibbons: 'needs a chief of staff'. tles over there on behalf of R\&D."

The Carnegie Commission was set up in order to consider science policy issues under the joint chairmanship of William Golden, treasurer of the American Association for the Advancement of Science, and Joshua Lederberg, the Nobel prizewinner and former president of Rockefeller University in New York.

The commission completed its work last autumn, and issued its memorandum on OSTP as a parting shot to guide the new administration. It argues that the OSTP director's effectiveness would be "greatly increased" if he interacted more intensively on a day-to-day basis with the president's senior staff. The appointment of a chief of staff would give the director more time to do that.

It also thinks that OSTP has too many priority programmes, and says that the powerful White House Office of Management and Budget (OMB) is reluctant to let OSTP set 'crosscuts', which calculate government spending in areas of research across several government agencies.

The memorandum admits that OSTP staff think that the relationship between the two offices has greatly improved. But it adds that "the view from OMB is more circumspect". It suggests a joint memorandum of understanding on the working relationship between the two offices.

Finally, the commission recommends that the NSTC's 60 or so working groups and subcommittees be pared back, and its resources concentrated on a small number of priority policy issues of concern to the president.

But it says that the overall structure for dealing with science and technology issues at the White House "is sound", and that the changes it suggests "are relatively minor".

Gibbons was in China last week with Vice-President Al Gore, and unavailable for comment. But Tim Newall, a spokesman for OSTP, said: "Overall we're pleased with the commission's endorsement of the steps we've taken to strengthen the science and technology policy making structure." The recommendations for change are "constructive suggestions which we'll take seriously".

But other observers were less charitable. The effectiveness of OSTP "has nothing to do with the structure, and everything to do with the person you have in there [as director] and their access to the president. All the rest is window dressing," says one physicist with extensive policy experience. 